\title{
Space for community - the study of resident involvement in neighbourhood space management
}

\author{
P. Castell \\ Built Environment and Sustainable Development, \\ Department of Architecture, Chalmers University of Technology, \\ Göteborg, Sweden
}

\begin{abstract}
The objects of study of this paper are groups of residents that are engaged in gardening and other management tasks in their neighbourhood. Such participation processes are sometimes promoted as a salvation of decline and eroded social capital in marginalised urban communities. This paper summarises experiences from previous Swedish case studies of resident involvement in open space management. It also proposes a revised classification model for the analysis, description and comparison of processes of resident involvement in neighbourhood space management in rental housing areas. The new typology is based on the level of autonomy, the management tasks, the type of contract and the type of compensation.
\end{abstract}

Keywords: participation, community garden, open space management, housing.

\section{Introduction}

This paper is an early outcome from the transdisciplinary research project "Sustainable open space management in rental housing areas" - aiming to collect knowledge on different management forms in relation to sustainable urban development, with a special focus on social and economic aspects. The purpose of the paper is to give an overview of different types of resident involvement in open space management in Sweden and present a model for their classification.

Participative management is promoted by different actors for a variety of reasons, but still often understood in practice by managers at housing companies as something unconventional and complicated or even strange [1]. 
As an area of research, resident involvement in neighbourhood space management deals with (a) the social structures within the neighbourhood; (b) the human-environment interaction in the daily outdoor activities; and (c) the institutional arrangements connecting the local community and its individuals to the housing company and the rest of the society with its cultural, economic and political macro-structures.

The paper is partly a literature review and partly built on my own empirical investigations carried out in the year of 2005: telephone interviews with different actors; observations in residential areas; questionnaires to residents; and deep interviews with residents and management staff.

\section{Definitions}

I will provide a brief explanation of the most central concepts of this paper. See Castell 2005 for a more elaborated discussion of the different terms [1].

The neighbourhood space is here a term for the public open space used for different types of everyday activities by the residents in a housing block or in a part of a residential area with rental apartments. In Sweden, rental apartment houses are in general organised in a way that each house or group of houses is connected to an open space, providing a nice view for the residents, tools for children's play, places to sit down, etcetera - a space shared by the residents. In many cases, this space is more or less enclosed by the buildings, whereby it forms a yard.

Involvement here refers to when local residents are engaged in the management of their neighbourhood spaces, doing practical work tasks such as planting, weeding, lawn moving, painting etcetera, but also tasks such as planning and designing the yard, or arranging social events for the neighbours. It may be regarded as a form of community gardening, which is a commonly used term for related phenomena. More organised forms of resident involvement are often called self-management. The participating residents are here referred to as active residents and the term process will function as a general term for the single project or active group in an area.

\section{Overview of Swedish case studies}

Resident participation in planning, design and decision-making has been an issue for research projects in Sweden since the 1970s. Very few projects, however, have aimed at investigating the specific role and functions of residential involvement in gardening and management of common open spaces. I will here briefly present some results from those projects and some related studies.

\subsection{Grassroots mobilisation and cooperative self-management in Eriksbo}

As the Social Democratic Party reassumed the power after six years of a rightwinged government in 1982, there was a lot of political debate on how to reorganise the public sector in Sweden. In connection to this, there were a 
number of members from the social democratic youth league who got interested in local community self-management. Some of them lived in the rental housing area Eriksbo in Göteborg, where they started to practice these ideas. They initiated a garden group, a sports club and a local magazine, and 1983 an areabased cooperative association was constituted. The process grew and led to institutionalised agreements. By the mid-1990s a school and a supermarket was run cooperatively and the association managed a public park in the area as well as indoor and outdoor maintenance through self-management contracts. However, the motivation fell for many of the active residents by the end of the 1990 s and the open space management is now contracted to a garden firm [3-8].

The case of Eriksbo is described in a number of reports highlighting the rather unique and highly developed local cooperative organisation. As sociologist J-E Lind points out, the researchers usually focus on the collaboration aspects, while the conflict aspects are less visible in most reports. According to Lind, collaboration and conflict are both inherent elements in any social process, and in the case of the self-management processes of Eriksbo, the collaboration patterns have been superior to the conflict patterns most of the time, until some years ago, when the conflict patterns became more visible [6].

\subsection{Self-management in Holma - a demonstration of urban revitalisation}

Holma was in the beginning of the 1990s a rather declined and stigmatised housing district in Malmö, even described in the newspapers as a 'human dump'. In an attempt to turn the vicious circle, the housing company looked for new ways of involving the residents. The district was divided into four management areas, with one local manager responsible for each. These areas were in turn divided into yard-wise 'self-management areas', and the residents were encouraged to form groups to involve in the management of the yards. Soon, most of the yards had self-management groups taking care of the maintenance.

The Holma project was a great success and has inspired many other companies. One thing that contributed to the renown of the project was that it triggered a political discussion on taxation on compensations, which eventually led to a new tax regulation (the 'Lex Holma'). Since then, it was made clear that untaxed economic compensation was acceptable, but only to a certain extent.

The evaluations and studies of Holma show the high potential of resident involvement in breaking a process of suburban decay and turn it to a positive rejuvenation process. They also show that it is possible to make economic arrangements to formalise and institutionalise resident involvement [7,8].

\subsection{The Poseidon project and the role of the Union of Tenants}

The Swedish Union of Tenants has played an important role in the development of different forms of resident empowerment in rental housing areas, and the collaboration between tenants and their landlords. The Union of Tenants has had a strong position with negotiation agreements with all municipal and most private housing companies. A prerequisite for many of the participation processes is the tenant influence agreements between the Union of Tenants and 
many of the companies, which provide a framework for collaboration. Despite being opponents in negotiations of rent levels and different types of conflicts, the two parts have very similar interests when it comes to social cohesion and the overall appearance of the residential area. Both the landlord and most residents benefit from a nice looking environment and good neighbour relations.

One of the outcomes from the collaboration between companies and the tenants' union, is the Local Democracy and Self-management (Lokal demokrati och självförvaltning) project of the municipal housing company Poseidon in Göteborg, which has been an object of a thorough evaluation. Since the start 1997, about thirty yard associations have formed, of which half are working with open space maintenance and management. The residents active in these groups do not get any direct compensation for their work. However, they are encouraged to apply for funds to purchase material and cover other expenses.

The evaluation of the Poseidon project gives an overall very positive view of the achievements, stating that a minimum of formal regulation (such as the relatively simple administration agreements of the yard associations) may give the residents a decent influence on their living situation. It also concludes that this kind of organisation involves some marginalised groups to a larger extent than traditional organisations; there is a fairly high amount of immigrants and women among the active in the yard associations [9].

\subsection{Community garden network in the centre of Stockholm}

As a step in the Agenda 21 work by the end of the 1990s, the project Green Living Yards (Grönskande levande gårdar) was set up in Stockholm's inner city, aiming to start and support what we may refer to as community gardens, where residents, school children or other user groups engaged in the development of management of a yard, playground, garden or such. Within two and a half year, more than 50 'yard groups' were formed who worked along with the project's process model in four steps (visioning, knowledge building, planning and implementation). There were some possibilities for the groups to apply for investment funds, but in general the money needed has been raised locally.

The intention was that strengthening of democratic collective action for the improvement of local environments would increase the overall awareness of environmental problems through. The evaluation of the project concludes that there was an increase in environmental awareness and engagement among the involved, although not remarkably high. It also highlights that the project was successful in creating nice and flourishing local environments and strengthening the social cohesion among the neighbours at the yards $[10,12]$.

\subsection{Some comparative studies of successful self-management processes}

There has been some few attempts learn from comparing different selfmanagement processes. One such study was carried out in the mid-1990s by the research institute Movium in Alnarp. They compared six processes in different parts of the country, of which three was in rental areas and three in tenantowners' associations areas. The focus of the study was to look at social effects, 
technical and environmental quality, and economic consequences. The presented results were very convincing in all aspects; the self-management had increased the social cohesion, the maintenance level was excellent and there were considerable economic savings compared to the estimated costs if the work would have been done by professionals [13].

More recently, a dissertation was published on participative management of municipal parks, based on eight case studies. It stressed that civic involvement can lead to improved maintenance and increased use. However, it also warned about some risks and problems connected to an uncertain division of responsibilities. This warning is probably less relevant for semi-public residential yards, with a more easily defined user group, than for fully public parks [14].

\subsection{A new research approach, comparing participative with non- participative management}

The last set of case studies I refer to here is the pre-studies made for the research project I am involved in together with researchers from other disciplines. My inventory of rental housing companies in Göteborg 2005 concluded that it was still unconventional with processes where the residents are involved in an organised way with the management of their yards. The 21 more organised processes of self-managed residential yards concerned less than $2 \%$ of the rental housing stock. They represented a broad variety of areas in terms of socioeconomic and demographic statistics as well as spatial configuration. However, all of them were within areas owned by municipal housing companies. Reasons to why there were no such processes in the privately owned rental housing areas could be (a) the generally smaller size of the private companies; (b) their weaker tradition of collaboration with the Union of Tenants; and (c) differences in business concept, where the politically decided commission of the municipal companies clearly encourage participative initiatives [1].

My colleague's comparative study between two areas, where one had resident self-management of the yards and the other was managed by a garden unit within the housing company, showed that the general feeling of responsibility was higher and the sense of anonymity was lower in the self-managed area [2].

Lastly, a still unpublished study where four yards in the same area, but with different types and levels of resident involvement, shows that there seems to be a strong connection between participative management and usage of the yard. However, it also points at potential problems with involvement processes as the empowerment of one group may create tensions and discord between the active and other residents. Or rather, when a group of neighbours start to meet regularly on the yard, hidden conflicts may come up to the surface and some groups may feel excluded.

\subsection{Conclusions from earlier experiences}

The direct impression when looking at all those case studies, and also when looking at similar studies from other countries, is that they are in general very 
optimistic about the phenomenon resident involvement in neighbourhood space management. There seem to be no reason to question that it may be a source to social capital building and diversified green living environments. One might wonder then, why such processes still are relatively uncommon.

The debate on self-management and resident involvement has been dominantly (and sometimes even naively) focused on the opportunities with collaboration rather than the risks for emerging conflicts and how to handle these challenges. The conflicts may be within the groups of active residents. Even more overlooked, are the conflicts between the active and other groups of residents. In many case studies, only the inside actors of a process are interviewed. Therefore it is of great interest to study the conflict part of resident involvement processes, and to be more careful of bringing in the perspectives of the non-active residents.

One example of where the case studies have made quite different conclusions is in the discussion on the role of economic compensation as a motive for residents to involve. Some studies state that economic compensation is an important incentive in the beginning of the process, but as it matures, the social exchange becomes the main driver [7,13]. Some studies rather count off economic incentives as being neglectable [9], while some sources stresses their importance also in the long term $[6,8]$.

What is clear is that there are many different kinds of processes of resident involvement in neighbourhood space management, and a more elaborated typology would be needed to understand, compare and discuss the differences. Even though there are some attempts to categorise different kinds of resident influence on general decisions about the management of the dwelling and residential area [15], there are hardly any models or typologies of different kinds of resident involvement in neighbourhood space management. Some models for analysing different kinds of resident involvement are presented in Castell 2005 [1], which will be developed further in this paper.

\section{A revised model for classification and studies of resident involvement in neighbourhood space management}

In Castell 2005 [1], four parameters are proposed for the analysis and description of a participative management process: (a) level of autonomy; (b) management tasks; (c) type of contract; and (d) type of compensation.

A high level of autonomy means that the resident group control the process; that they independently can decide on how they want to work and what they want to do. A low level of autonomy means that the group has less control; that they are dependent on conditioned support or need approval from the housing company on their decisions. There is a formal component of the control, which is connected to the existence of written agreements (see below), but the factual level of autonomy may be very dependent on informal circumstances.

There is a broad set of management tasks included in the management of residential yards. Some residential groups engage in just some parts of the management work, such as e.g. planting and tending some flower beds. Other 
groups have a more comprehensive responsibility for the yard, including planning, design and economical prioritisation.

In formalised involvement processes there are different types of contracts, in which the responsibilities and economic frames are regulated. A contract refers to a written agreement signed by the resident group and the housing company. Some groups may have more or less explicit and detailed oral agreements with representatives from the housing company or a contracted manager. In this paper, oral agreements are counted as non-contracted, as they give a very low degree of formal regulation in a conflict situation. A self-management process without any recognition by the formal management organisation is not probable in the contemporary Swedish context.

There are also different arrangements for giving the residents compensation for their involvement. Active resident groups usually get some support from the housing company, even though there are examples of groups working totally independent of the formal management organisation. Common is that the company pays for flowers and other material, and that they sponsor some social arrangements. What is here called compensation, however, is when the residents in a regulated form receive economic compensation for the work they do. I may be in form of a yearly management fund; it may be in form of rent reduction or payments to the active residents; or sometimes to all the residents within the area. Often there is a combination of collective and individual compensations.

Except from those four parameters, there are a number of other highly relevant aspects for describing and analysing participative yard management processes, such as (a) the number of involved residents and how much time they spend in the management; (b) the size of the residential area in terms of population and land; (c) its spatial configuration; (d) its geographical location in connection to the city centre; (e) the size of the maintenance area and its content; (f) demographic composition; and (g) the initiative and history of the process. These are interesting aspects that may complement the four parameters described above.

\subsection{A proposed classification system}

A good start for describing and comparing processes of resident involvement in neighbourhood space management is thus to look at which level of autonomy the group of residents have in the process; which management tasks they take responsibility for; and which type of contract and compensation they have. These parameters also constitute the foundation for the typology presented below, where the parameters have been used for classifying different types of processes. It is important to note that we have already narrowed the scope to treat continuous management processes and not than just temporary projects such as participative planning processes in connection to renovations etcetera; we deal with residential yards within rental housing areas and not tenant-owner's associations; and we keep to processes of collective action and not involvement by single individuals.

The classification first differs between three main types of collective resident involvement: (a) self-management; (b) supervised self-management; and 
(c) garden groups. This first categorisation is based on the level of autonomy and the width of management tasks undertaken. Secondly, there are sub-categories within each of the three main classes, which depend on the type of contract and compensation (see figure 1).

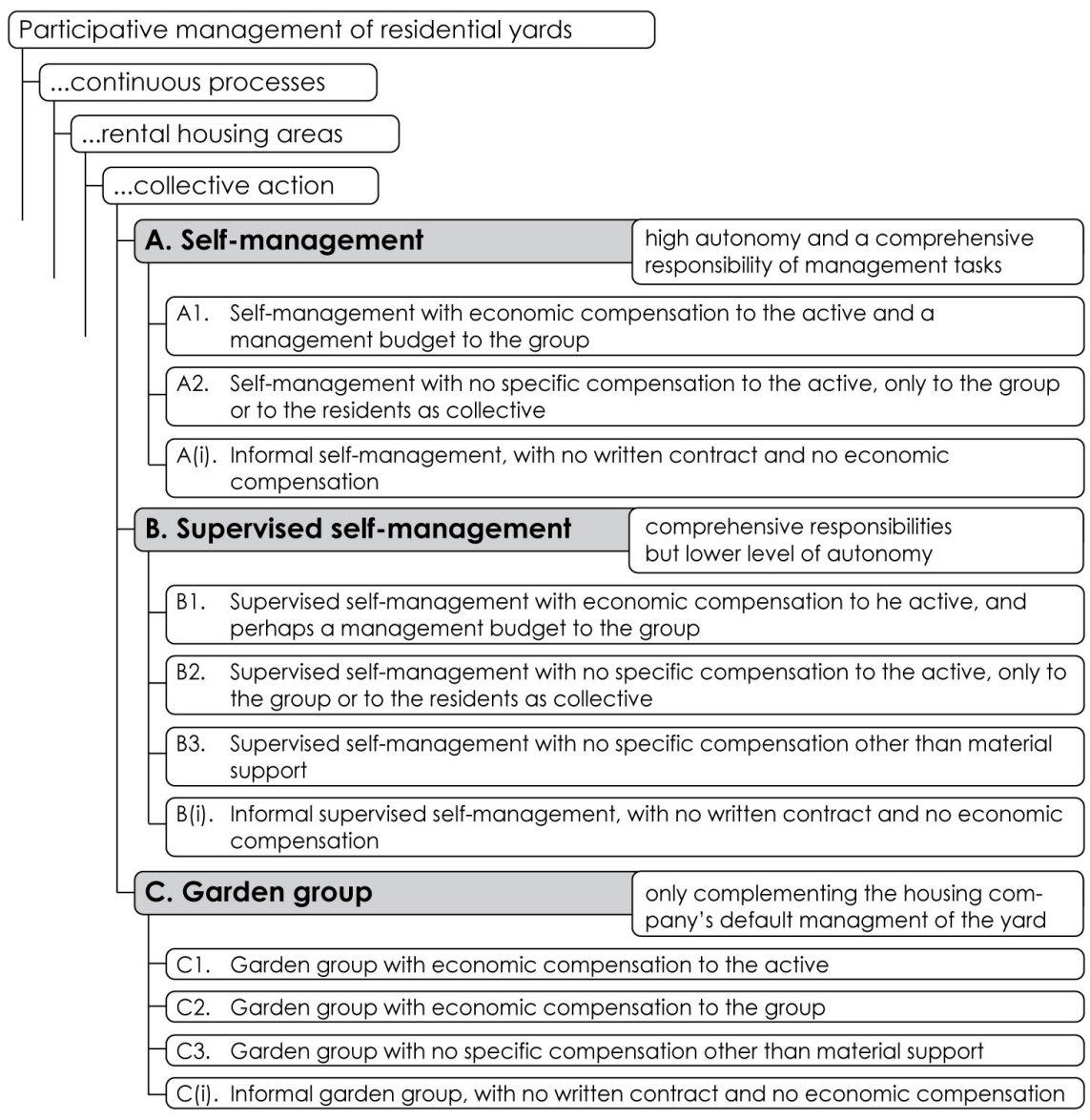

Figure 1: Classification of participative residential yard management processes.

A. Self-management refers to processes where the residents have full control of prioritisation within the overall management budget frames. This means that they work with a broad set of management tasks compared to the garden groups. It is difficult to find studies of this kind of fully autonomous processes, except from the extensive cooperative self-management in Eriksbo during the first part of the 1990s. However, my studies show that there is a number of this kind of processes existing in Göteborg, representing sub-category A1 and A2. 
B. Supervised self-management refers to processes where decisions on investments and changed designs must be agreed on by the housing company; thus a lower degree of autonomy than the self-management processes. However, they still work with a broader set of management tasks compared to the garden groups. Most of the cases referred to as self-management processes in the literature belong to this category as they do not have full autonomy. I have found examples of the sub-categories B3 and B(i) in Göteborg. The processes in Holma represent the sub-category B1.

C. Garden group refers to processes where the residents' contribution to the management is only a complement to the maintenance work done by the housing company. Often the tasks are additions to the 'normal' maintenance, as a result of new functions requested by the residents, such as tending new flower beds or taking care of a compost bin. Within the limited set of management tasks, the group may be more or less autonomous in decision-making. There is a number of garden groups in Göteborg, representing all four sub-categories.

\section{Final remarks and conclusions}

As repeatedly stated in the debate on sustainable development, it is of high importance to refine existing and to develop new forms of civic participation in local decision-making and planning processes $[16,17]$. We must move from a culture of top-down government to a more communicative governance $[18,19]$. The civil unrest leading to violent riots in France in October and November 2005 gave news-watchers over the world an illustration of the vulnerability of a society with highly stigmatised and segregated suburban residential areas. For many, those events were strong arguments for increasing the efforts to empower marginalised groups and support constructive local initiatives.

Resident involvement in neighbourhood space management exemplifies such positive grassroots engagement initiatives, and has proven to diversify the green environment as well as improve the social cohesion. Previous research has proven that, but there are still knowledge gaps that need thorough investigation to fill. There is a need to better understand the challenges involved with such processes, particularly from a democracy and social conflict perspective. There is also a need to get an overview of which different arrangements are in use and how common they are. And what contextual factors support or hinder initiatives of participative management processes and their institutionalisation.

The intention with the proposed analytical model and classification is to provide a useful tool for such studies.

\section{References}

[1] Castell, P., Resident involvement in neighborhood space management; a survey among housing companies in Göteborg. Proc. of the International Conference for Integrating Urban Knowledge \& Practice, Göteborg 29 May - 3 June, 2005, www.urbanlife2005.com/proceedings/E/209 Pal Castell.pdf 
[2] Lindgren, T., How can management of estate grounds make a difference to people's quality of life on brownfield sites. Proc. of Cabernet 2005 The International Conference on Managing Urban Land, Belfast, 2005.

[3] Modh B., A housing area developed in a complex cultural context, in Krantz B., Öresjö E. \& Priemus H., eds., Large scale housing estates in North-West Europe: problems, interventions and experiences, Delft University Press, Delft (NL), 1999.

[4] Modh, B., Eriksbo; lokalt engagemang och bebyggelseförändringar, Chalmers, Göteborg, 1996.

[5] Törnquist, A., Till förortens försvar : utveckling och organisering $i$ de tre stadsdelarna Hjällbo, Hammarkullen, Eriksbo 1970-1995, Department of Social Work, Göteborg University, 2001.

[6] Olsson, S., Lind, J.-E. \& Björck, L., Framtidens stadsdelsutveckling : 1993-2004, Förvaltnings AB Framtiden, Göteborg, 2005.

[7] Alfredsson, B. \& Cars, G., De boende som medarbetare; självförvaltning $i$ Holma, SABO Utveckling, Enskede, 1996.

[8] Sundling, J., Levande självförvaltning; ett reportage om bostäder och demokrati, Boinstitutet, Stockholm, 1999.

[9] Bengtsson, B., Berger, T., Fransson, N., Lind, J.-E. \& Modh, B., Lokal kontroll och kollektivt handlande; en utvärdering av självförvaltning $i$ Bostads AB Poseidon i Göteborg, Uppsala University, 2003.

[10] City of Stockholm, Slutrapport för projektet Grönskande levande gårdar Agenda 21 innerstaden, Stockholm, 2002.

[11] Ericson, U., Gårdar och livsstil $i$ förändring, Stockholm Office of Research and Statistics, City of Stockholm, 2002.

[12] Cele, S., Förändringsprocesser på gårdar, Stockholm Office of Research and Statistics, City of Stockholm, 2002.

[13] Berglund, U., Hansson, T., Hägg, T., Jergeby, U. \& Söderblom, P., Vi vårdar vår gård, Swedish University of Agricultural Sciences, Alnarp, 1995.

[14] Delshammar, T., Kommunal parkverksamhet med brukarmedverkan, Swedish University of Agricultural Sciences, Alnarp, 2005.

[15] Bengtsson, B. \& Berger, T., Gräsrot, språkrör och träffpunkt : lokal organisering och demokrati $i$ boendet, Institutet för bostadsforskning, Gävle, 2005.

[16] United Nations Conference on Environment and Development (UNCED). Agenda 21. United Nations, New York, 1992.

[17] United Nations Human Settlements Programme (UN-Habitat). The Habitat Agenda Goals and Principles, Commitments and the Global Plan of Action. Proc. of United Nations Conference on Human Settlements (Habitat II), Istanbul 30-31 May, 1996.

[18] Healey, P., Collaborative planning: shaping places in fragmented societies. Macmillan, Basingstoke, 1997.

[19] Malbert, B., Urban planning participation: linking practice and theory. Chalmers University of Technology, Göteborg, 1998. 